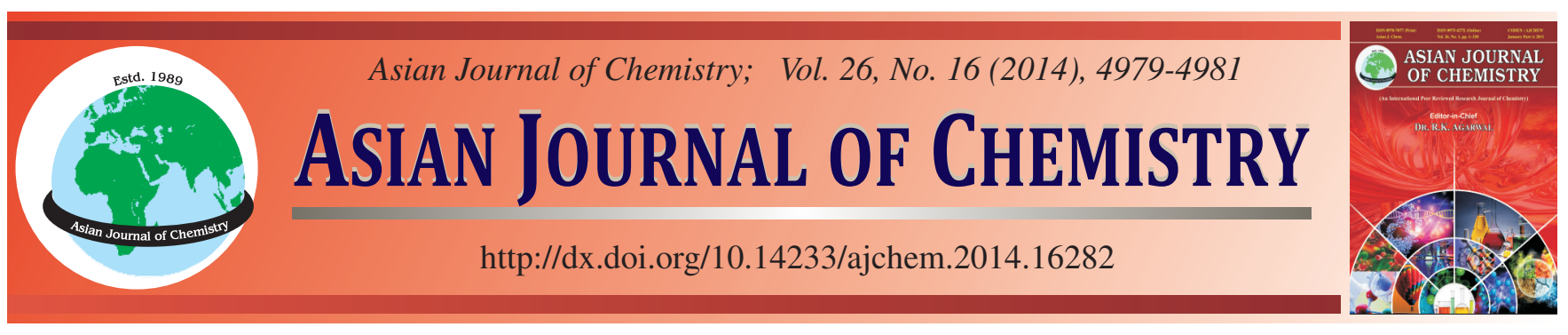

\title{
Antioxidant Activity and Antioxidant Mechanism of Brazilin and Neoprotosappanin from Caesalpinia sappan Lignum
}

Feng-Zheng Chen ${ }^{\dagger}$, Qi Zhao ${ }^{\dagger}$, Jun Yan, Xiao-Qiang Guo, Qin Song, Qian Yao and XiaO-Jun Gou*

Key Laboratory of Meidicinal and Edible Plant Resources Development of Sichuan Education Department, Chengdu University, Chengdu 610106, P.R. China

$†$ These authors contributed equally to this work

*Corresponding author: E-mail: jmee@cdu.edu.cn

Received: 4 September 2013;

Accepted: 31 December 2013;

Published online: 28 July 2014;

AJC-15614

The compounds, brazilin and neoprotosappanin, have been isolated from Caesalpinia sappan Lignum. The structures were charaterized by NMR spectra. The antioxidant activity of brazilin and neoprotosappanin were evaluateded by using free radical scavenging assays, namely $1,1^{\prime}$-diphenyl-2-picrylhydrazyl. The $\mathrm{IC}_{50}$ values of brazilin and neoprotosappanin are 0.067 and $0.375 \mu \mathrm{g} / \mathrm{mL}$, respectively, much higher than the $\mathrm{IC}_{50}$ of vitamin $\mathrm{C}, 0.542 \mu \mathrm{g} / \mathrm{mL}$. The result shows that brazilin and neoprotosappanin possess powerful antioxidant activity, which can be used as function-rich antioxidants and whose application promising are very extensive.

Keywords: Caesalpinia sappan Lignum, Brazilin, Neoprotosappanin, Antioxidant activity, Antioxidant mechanism.

\section{INTRODUCTION}

Caesalpinia sappan $\mathrm{L}$ is distributed mainly in southeast Asia, especially around the southwest of China. The stems of Caesalpinia sappan $\mathrm{L}$ can be used as herbal medicine, which has been used as a remedy for blood stasis, detumescence analgesic efficacy, indications of amenorrhoea dysmenorrhoea, postpartum blood stasis, thoracic and abdominal pain, traumatic swelling and pain and so on ${ }^{1}$. In previous research, some compounds were isolation and identification from Caesalpinia sappan $\mathrm{L}$ and they have a broad range of demonstrated pharmacological properties e.g., antihepatotoxicity, antiplatelet activity and antiinflammatory activities, etc $^{2-7}$. To our best of knowledge, no previous work has been reported on the antioxidant activity of neoprotosappanin, while the antioxidant activity of brazilin were rarely reported, too.

In the present study, we evaluated the antioxidant activity of brazilin and neoprotosappanin from Caesalpinia sappan Lignum by using free radical scavenging assays, namely 1,1 'diphenyl-2-picrylhydrazyl and proposed their antioxidant mechanism.

\section{EXPERIMENTAL}

Caesalpinia sappan Lignum was collected in Chengdu Chinese herbal medicine market, Sichuan province of China in April 2011 and authenticated by Professor Yue-Hua Wang of the Chengdu University, where a voucher specimen has deposited. 1,1'-Diphenyl-2-picrylhydrazyl was puchased from Sigma Chemicals Co. (St. Louis, Mo, USA). All chemicals and solvents used were of analytical grade.

NMR spectra were measured on a Bruker DRX-400 instrument with TMS as internal standard. Column chromatography was performed on silica gel (200-300 mesh; Qingdao Marine Chemical Inc.). Thin-layer chromatography (TLC) was carried out on silica gel 60 F254 on glass plates (Qingdao Marine Chemical Inc.) using various solvent systems.

Extraction and isolation: Dry Caesalpinia sappan Lignum $(2 \mathrm{~kg})$ were extracted with ethanol $(3 \times 5 \mathrm{~L})$ for $24 \mathrm{~h}$. The extract was suspended in water $(1000 \mathrm{~mL})$ to form a suspension and degreased with petroleum ether and then extracted with EtOAc. The EtOAc extract (15.8 g) was chromatographed on a silica gel column employing cyclohexane-acetone $(3: 1$ $\rightarrow 1: 3$ ) as eluent to provided five fractions. After repeatedly column chromatography of five fractions over a silica gel column using $\mathrm{CHCl}_{3}-\mathrm{CH}_{3} \mathrm{OH}(20: 1 \rightarrow 4: 1)$ as eluent afforded brazilin (260 mg) and neoprotosappanin (25 mg).

1,1'-Diphenyl-2-picrylhydrazyl radical scarenging activity: Free radical scavenging activity of brazilin and neoprotosappanin were measured by (1,1'-diphenyl-2-picrylhydrazyl) using vitamin $\mathrm{C}$ as positive control. In brief, a solution of 1,1'-diphenyl-2-picrylhydrazyl in methanol (0.507 $\mathrm{mM}$ ) was prepared. Then, $100 \mathrm{~mL}$ of this solution was added to $4.9 \mathrm{~mL}$ of brazilin or neoprotosappanin or vitamin $\mathrm{C}$ solution at different doses. The mixture was then shaken and allowed 
to stand at room temperature for $0.5 \mathrm{~h}$, with the absorbance measured at $517 \mathrm{~nm}$ in a spectrophotometer against blank samples. Radical scavenging capacity was expresses as percentage effect (E \%) or inhibition percentage (\%) and calculated using the following equation:

$$
\text { Percentage effect }(\mathrm{E} \%)=\frac{\left(\mathrm{Abs}_{\text {control }}-\mathrm{Abs}_{\text {sample }}\right)}{\mathrm{Abs}_{\text {control }}} \times 100
$$

Inhibition percentage $(\mathrm{IC} \%)=1$-percentage effect $(\mathrm{E} \%)$

Different sample concentrations were used to obtain antiradical cures for calculating the $\mathrm{EC}_{50}$ or $\mathrm{IC}_{50}$ values. Antiradical curves were plotted referring to concentration on the $\mathrm{x}$ axis and their relative scavenging capacity on the $\mathrm{y}$ axis. The $\mathrm{EC}_{50}$ or $\mathrm{IC}_{50}$ values were processed using five different statistical programs $^{8}$.

Statistical analysis: Mean data values are presented with standard error of the mean (mean $\pm \mathrm{SD}$ ). Analysis of variance followed by Dunnett's test for pairwise comparison was used for statistical validation of the data, with significance defined as $\mathrm{p}<0.05$.

\section{RESULTS AND DISCUSSION}

The compounds (Fig. 1), brazilin and neoprotosappanin were identified by comparison of their ${ }^{1} \mathrm{H}$ and ${ }^{13} \mathrm{C}$ NMR spectra with values reported in the literature ${ }^{4-5}$ and their spectra data are given below:

Brazilin: Yellow amorphous powder: ${ }^{1} \mathrm{H} \mathrm{NMR}(400 \mathrm{MHz}$, DMSO- $d_{6}$ ) and ${ }^{13} \mathrm{C}$ NMR: (100 MHz, DMSO- $d_{6}$ ), (Table-1).

Neoprotosappanin: Yellow amorphous powder: ${ }^{1} \mathrm{H}$ NMR (400 MHz, DMSO- $d_{6}$ ) and ${ }^{13} \mathrm{C}$ NMR: (100 MHz, DMSO- $d_{6}$ ), (Table-1).

1,1'-Diphenyl-2-picrylhydrazyl radical scavenging activity: $\mathrm{DPPH}^{\bullet}$ assay is a reliable method to determine the antioxidant capacity of biological substrates and $\mathrm{EC}_{50}$ or $\mathrm{IC}_{50}$ is generally used as an indicator of antioxidant capacity for<smiles>Cc1cc(O)c(O)cc1C1c2ccc(O)cc2OCC1(C)O</smiles><smiles>O=COCCOCCOc1cc2c(cc1O)C1c3cc(O)c(O)cc3CC1(O)COc1cc(O)c(O)cc1-2</smiles>

Fig. 1. Structures of brazilin and neoprotosappanin

plant extracts and pure compounds. The inhibition percentage (IC \%) of samples are shown in Table-2.

Vitamin C, brazilin and neoprotosappanin exhibited appreciable scavenging properties against the radical and the inhibition percentages were proportional to the concentration of the sample. The $\mathrm{IC}_{50}$ values for brazilin and neoprotosappanin, vitamin $C$ were $0.067 \mu \mathrm{g} / \mathrm{mL}, 0.375$ and $0.542 \mu \mathrm{g} / \mathrm{mL}$, respectively. The experimental results indicate that brazilin and neoprotosappanin have more powerful antioxidants than vitamin $\mathrm{C}$ and brazilin possess most powerful antioxidants among them.

\begin{tabular}{|c|c|c|c|c|c|c|c|c|}
\hline \multirow[b]{3}{*}{ Position } & \multicolumn{7}{|c|}{ TABLE-1 } & \\
\hline & \multicolumn{2}{|r|}{ Brazilin } & \multicolumn{3}{|c|}{ Neoprotosappanin } & \multicolumn{3}{|c|}{ Neoprotosappanin } \\
\hline & $\delta$ & $\delta_{\mathrm{H}}$ & $\begin{array}{l}\text { Unit } \\
\text { I }\end{array}$ & $\delta$ & $\delta_{\mathrm{H}}$ & $\begin{array}{l}\text { Unit } \\
\text { II }\end{array}$ & $\delta$ & $\delta_{\mathrm{H}}$ \\
\hline 1 & - & - & 1 & - & - & 1 & - & - \\
\hline 2 & 69.9 & $\begin{array}{l}3.85(\mathrm{~d}, 1 \mathrm{H}, J=11.2 \mathrm{~Hz}) \\
3.57(\mathrm{~d}, 1 \mathrm{H}, J=11.2 \mathrm{~Hz})\end{array}$ & 2 & 71.0 & $\begin{array}{l}3.96(\mathrm{~d}, 1 \mathrm{H}, J=11.2 \mathrm{~Hz}) \\
4.01(\mathrm{~d}, 1 \mathrm{H}, J=11.2 \mathrm{~Hz})\end{array}$ & 2 & 70.8 & $\begin{array}{c}3.88(\mathrm{~d}, 1 \mathrm{H}, J=11.2 \mathrm{~Hz}) \\
3.65(\mathrm{~d}, 1 \mathrm{H}, J=11.2 \mathrm{~Hz})\end{array}$ \\
\hline 3 & 76.6 & - & 3 & 80.4 & - & 3 & 78.0 & - \\
\hline 4 & 49.8 & $3.84(\mathrm{~s}, 1 \mathrm{H})$ & 4 & 50.2 & $4.01(\mathrm{~s}, 1 \mathrm{H})$ & 4 & 51.0 & $4.01(\mathrm{~s}, 1 \mathrm{H})$ \\
\hline 5 & 131.2 & $7.14(\mathrm{~d}, 1 \mathrm{H}, J=8.4 \mathrm{~Hz})$ & 5 & 131.8 & $7.19(\mathrm{~d}, 1 \mathrm{H}, J=8.4 \mathrm{~Hz})$ & 5 & 133.6 & $6.72(\mathrm{~s}, 1 \mathrm{H})$ \\
\hline 6 & 109.0 & $6.42(\mathrm{dd}, 1 \mathrm{H}, J=2.4,8.4 \mathrm{~Hz})$ & 6 & 109.8 & $6.42(\mathrm{dd}, 1 \mathrm{H}, J=2.4,8.4 \mathrm{~Hz})$ & 6 & 120.1 & \\
\hline 7 & 156.8 & - & 7 & 157.6 & - & 7 & 156.2 & - \\
\hline 8 & 103.0 & $6.21(\mathrm{~d}, 1 \mathrm{H}, J=2.4 \mathrm{~Hz})$ & 8 & 104.0 & $6.29(\mathrm{~d}, 1 \mathrm{H}, J=2.4 \mathrm{~Hz})$ & 8 & 104.0 & $6.37(\mathrm{~s}, 1 \mathrm{H})$ \\
\hline 9 & 42.2 & $\begin{array}{l}2.70(\mathrm{~d}, 1 \mathrm{H}, J=15.6 \mathrm{~Hz}) \\
2.87(\mathrm{~d}, 1 \mathrm{H}, J=15.6 \mathrm{~Hz})\end{array}$ & 9 & 49.1 & $4.49(\mathrm{~s}, 1 \mathrm{H})$ & 9 & 42.8 & $\begin{array}{c}2.71(\mathrm{~d}, 1 \mathrm{H}, J=15.6 \mathrm{~Hz}) \\
2.97(\mathrm{~d}, 1 \mathrm{H}, J=15.6 \mathrm{~Hz})\end{array}$ \\
\hline $2^{\prime}$ & 112.3 & $6.64(\mathrm{~s}, 1 \mathrm{H})$ & $2^{\prime}$ & 114.0 & $6.57(\mathrm{~s}, 1 \mathrm{H})$ & $2^{\prime}$ & 112.5 & $6.55(\mathrm{~s}, 1 \mathrm{H})$ \\
\hline $3^{\prime}$ & 144.6 & & $3^{\prime}$ & 145.4 & & $3^{\prime}$ & 145.3 & \\
\hline $4^{\prime}$ & 144.2 & & $4^{\prime}$ & 145.7 & & $4^{\prime}$ & 145.4 & \\
\hline $5^{\prime}$ & 111.9 & $6.55(\mathrm{~s}, 1 \mathrm{H})$ & $5^{\prime}$ & 112.6 & $6.87(\mathrm{~s}, 1 \mathrm{H})$ & $5^{\prime}$ & 112.6 & $6.43(\mathrm{~s}, 1 \mathrm{H})$ \\
\hline $6^{\prime}$ & 135.8 & & $6^{\prime}$ & 135.1 & & $6^{\prime}$ & 135.3 & \\
\hline $4 a$ & 114.6 & & $4 a$ & 115.8 & & $4 a$ & 115.2 & \\
\hline $8 \mathrm{a}$ & 154.3 & & $8 \mathrm{a}$ & 155.6 & & $8 \mathrm{a}$ & 154.4 & \\
\hline
\end{tabular}




\begin{tabular}{cccc}
\hline \multirow{4}{*}{ TABLE-2 } & \\
INHIBITION PERCENTAGE (IC \%) OF SAMPLES \\
\hline \multirow{3}{*}{ Sample } & $\begin{array}{c}\text { Final } \\
\text { concentration } \\
(\mu \mathrm{g} / \mathrm{mL})\end{array}$ & $\begin{array}{c}\text { Inhibition } \\
\text { percentage } \\
(\mathrm{IC} \%)\end{array}$ & $\begin{array}{c}\mathrm{IC}_{50} \\
(\mu \mathrm{g} / \mathrm{mL})\end{array}$ \\
\hline \multirow{4}{*}{ Brazilin } & 0.50000 & 76.83 & \\
& 0.25000 & 70.12 & \\
& 0.12500 & 57.30 & 0.067 \\
& 0.06250 & 49.08 & \\
Neoprotosappanin & 0.03125 & 41.76 & \\
& 1.0000 & 85.97 & \\
& 0.5000 & 70.12 & \\
& 0.2500 & 46.34 & 0.375 \\
& 0.1250 & 30.49 & \\
& 0.0625 & 21.26 & \\
\hline \multirow{5}{*}{ Vitamim C } & 1.0000 & 79.88 & \\
& 0.5000 & 48.17 & \\
& 0.2500 & 27.44 & 0.542 \\
& 0.1250 & 24.22 & \\
\hline
\end{tabular}

Free radical is a major factor causing many serious diseases. Brazilin and neoprotosappanin have powerful antioxidant activity, so they can clear away free radical in human body, guard against diseases and postpone senility. The experiment results indicate that brazilin and neoprotosappanin have more powerful antioxidants than vitamin $\mathrm{C}$ and brazilin is a potential source of antioxidant compound.

Antioxidant mechanism: The antioxidant activity of brazilin and neoprotosappanin may be due to the phenolic hydroxyl groups which have very strong effects on antioxidation and elimination of free radical. Due to a high degree of structural similarity, the antioxidant mechanism of brazilin and neoprotosappanin may be similar. The antioxidant mechanism of brazilin is shown in Fig. 2.

\section{ACKNOWLEDGEMENTS}

This work financially was supported by Chengdu Science and Technology Bureau (No. 12DXYB155JH-002) and Science and Technology Department of Sichuan Province (No.

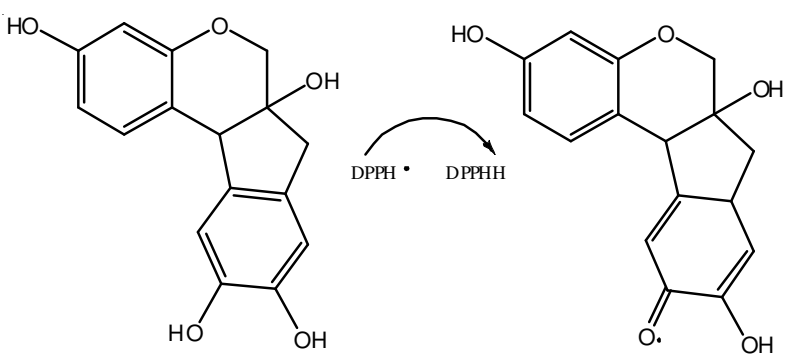
2014JY0144).

\section{REFERENCES}

1. M.J. Chu, Y.Z. Wang, K. Itagaki, H.-X. Ma, P. Xin, X.-G. Zhou, G.-Y. Chen, S. Li and S.-Q. Sun, J. Ethnopharmacol., 148, 37 (2013).

2. M.T.T. Nguyen, S. Awale, Y. Tezuka, Q.L. Tran and S. Kadota, Tetrahedron Lett., 45, 8519 (2004).

3. B.O. Yang, C.Q. Ke, Z.S. He, Y.- Yang and Y. Ye, Tetrahedron Lett., 43, 1731 (2002).

4. M. Namikoshi, H. Nakata, H. Yamada, M. Nagai and T. Saitoh, Chem. Pharm. Bull. (Tokyo), 35, 2761 (1987).

5. M.T. Nguyen, S. Awale, Y. Tezuka, Q.L. Tran and S. Kadota, Chem. Pharm. Bull. (Tokyo), 53, 984 (2005).

6. M.Y. Lim, J.H. Jeon, E.Y. Jeong, C.-H. Lee and H.-S. Lee, Food Chem., 100, 1254 (2007).

7. J. Hu, X.L. Yan, W. Wang, H. Wu, L. Hua and L. Du, Tsinghua Sci. Technol., 13, 474 (2008).

8. Z. Chen, R. Bertin and G. Froldi, Food Chem., 138, 414 (2013).

Fig. 2. Possible antioxidant mechanism of brazilin scavenging 1,1'diphenyl-2-picrylhydrazyl radical 